\title{
Isolasi dan Identifikasi Senyawa Flavonoid Ekstrak Etanol Buah Naga Merah (Hylocereus polyrhizus (F.A.C.Weber)Briton \& Rose)
}

(Isolation and Identification of Flavonoid Compounds from Ethanol Extract of Red Dragon Fruits (Hylocereus polyrhizus (F.A.C.Weber) Briton \& Rose)

\author{
Siti Nuari, Syariful Anam, Akhmad Khumaidi
}

Jurusan Farmasi, Fakultas MIPA, Universitas Tadulako, Palu, 94118

\author{
Article Info: \\ Received: 08April 2017 \\ in revised form: 22 April 2017 \\ Accepted: 30 Mei 2017 \\ Available Online: 01Oktober 2017 \\ Keywords: \\ Hylocereus polyrhizus, \\ isolation, \\ flavanones \\ Corresponding Author: \\ Siti Nuari \\ Jurusan Farmasi, \\ Fakultas MIPA, \\ Universitas Tadulako, \\ 94118, Palu, Indonesia \\ Phone :+62-8524-2696-488 \\ Email: shetinuari@yahoo.co.id
}

\begin{abstract}
The isolation and identification of flavonoid compounds from ethanol extract of red dragon fruit (Hylocereus polyrhizus (F.A.C.Weber) Briton \& Rose) have been done. Red dragon fruit extract was obtained by maceration of dragon fruit powder with $96 \%$ ethanol. The ethanol extract was then partitioned by liquid-liquid partition method using n-hexane, ethyl acetate and water, respectively. Ethyl acetate extract was separated by vacuum liquid chromatography, while the water extract was first hydrolyzed by $\mathrm{HCl}$ and then partitioned with ethyl acetate (ethyl acetate fraction). The results of the purification of the ethyl acetate extract by preparative TLC yielded five isolates. However, only the third isolates were positive flavonoid compounds. The UV-Vis spectral data of three isolates showed a peak at 330 $\mathrm{nm}$ (band I) and $280 \mathrm{~nm}$ (band II), and the addition of the diagnostic reagents did not show bathochromic and hipsochromic shifting. Based on the obtained data, the third isolate was suspected flavanones compound.
\end{abstract}

How to cite (APA 6th Style):

Nuari S., Anam S., Khumaidi A. (2017). Isolasi dan Identifikasi Senyawa Flavonoid Ekstrak Etanol Buah Naga Merah (Hylocereus polyrhizus (F.A.C.Weber)Briton \& Rose). Jurnal Farmasi Galenika : Galenika Journal of Pharmacy, 3(2), 118125. doi:10.22487/j24428744.2017.v3.i2. 


\begin{abstract}
ABSTRAK
Telah dilakukan penelitian mengenai isolasi dan identifikasi senyawa flavonoid dari ekstrak etanol buah naga merah (Hylocereus polyrhizus (F.A.C.Weber) Briton \& Rose). Ekstrak buah naga merah diperoleh melalui maserasi serbuk buah naga merah dengan pelarut etanol $96 \%$. Ekstrak etanol yang diperoleh di partisi dengan metode partisi cair-cair menggunakan pelarut $n$-heksana, etil asetat dan air. Hasil partisi ekstrak etil asetat kemudian dilakukan pemisahan dengan Kromatografi vakum cair, sedangkan ekstrak air dihidrolisis terlebih dahulu dengan $\mathrm{HCl}$ lalu dipartisi dengan etil asetat (fraksi etil asetat). Berdasarkan hasi pemurnian ekstrak etil asetat dan fraksi etil asetat dengan KLT Preparatif diperoleh 5 isolat tetapi hanya isolat 3 yang positif senyawa flavonoid. Hasil spektroskopi UV-Vis isolat 3 menghasilkan puncak pada $330 \mathrm{~nm}$ (pita I) dan $280 \mathrm{~nm}$ (pita II), sedangkan pada penambahan pereaksi geser tidak mengalami pergeseran batokromik dan hipsokromik. Berdasarkan data-data yang diperoleh isolat 3 diduga merupakan golongan senyawa flavanon.
\end{abstract}

Kata Kunci : Hylocereus polyrhizus (F.A.C.Weber) Briton \& Rose, isolasi, flavanon.

\section{PENDAHULUAN}

Penggunaan tanaman sebagai bahan obat tradisional memerlukan penelitian ilmiah untuk mengetahui kebenaran khasiatnya. Penggunaan tanaman sebagai obat dapat dijamin kebenarannya dengan didapatkannya data yang meyakinkan secara ilmiah. Contoh tanaman yang digunakan sebagai tanaman obat yaitu tanaman jenis kaktus, salah satu jenis kaktus yang saat ini sudah dikenal di Indonesia adalah buah naga (Dragon fruits). Sejak diperkenalkan pertama kali dalam expo "Agriteec" di Tokyo tahun 1999, buah naga kian popular dan banyak diminati orang karena memiliki rasa enak dan banyak khasiat. Adapun jenis buah naga yang telah dibudidayakan ada empat yaitu buah naga berdaging putih (Hylocereus undatus), buah naga berdaging merah (H. polyrhizus), buah naga berdaging super merah $(H$. costaricensis), dan buah naga berkulit kuning dengan daging putih (Selenicereus megalanthus) (Winarsih, 2007).

Buah naga memiliki berbagai khasiat antara lain dapat menurunkan kadar kolesterol, menyeimbangkan kadar gula darah, mencegah terjadinya kanker usus, menguatkan daya kerja otot serta dapat menghaluskan kulit. Secara umum buah ini bermanfaat untuk kesehatan dan dapat memenuhi kebutuhan tubuh akan zat gizi sehari-hari (Winarsih, 2007). Buah naga memiliki kandungan kimia flavonoid, fenolik, polifenol (Jaafar et al, 2009). Flavonoid adalah kelompok senyawa fenolik alam yang mempunyai bioaktifitas sebagai obat. Flavonoid terdapat dalam semua tumbuhan hijau dan merupakan metabolit sekunder yang menunjukkan berbagai khasiat farmakologi (Rohyami, 2008).
Hasil penelitian Feranose (2009), flavonoid pada buah naga merah diketahui dapat menurunkan kadar glukosa darah. Senyawa flavonoid seperti isoflavon berkhasiat dapat mencegah timbulnya kanker prostat, menurunkan resiko terkena penyakit jantung, diabetes, ginjal dan osteoporosis (Asih, 2012). Senyawa flavonoid lain dalam golongan flavanolol berkhasiat sebagai antiinflamasi, antioksidan dan juga antikanker serta senyawa flavanon berkhasiat sebagai antibakteri (Patni et al, 2008).

Berdasarkan hal tersebut perlu dilakukan pengkajian lebih lanjut untuk mengetahui jenis senyawa flavonoid dengan melakukan isolasi dan identifikasi ekstrak buah naga merah, sehingga pemanfaatan buah naga merah untuk kesehatan dapat dijelaskan secara ilmiah.

\section{METODE PENELITIAN Alat Penelitian}

Alat-alat yang digunakan pada penelitian ini yaitu gelas ukur (IWAKI PIREX $\left.{ }^{\circledR}\right)$, gelas kimia (IWAKI PIREX $\left.{ }^{\circledR}\right)$,blender, pipa kapiler, corong kaca (IWAKI PIREX ${ }^{\circledR}$ ), erlenmeyer (IWAKI PIREX ${ }^{\circledR}$ ), labu takar (IWAKI PIREX ${ }^{\circledR}$ ), bejana maserasi, kertas saring, chamber KLT, timbangan analitik $\left(O H A U S^{\circledR}\right)$, hot plate (VENDILLE ${ }^{\circledR}$ ), vacuum rotary evaporator $\left(E Y E L A^{\circledR}\right)$,cawan porselen, oven $\left(\right.$ SHELLAB $\left.^{\circledR}\right)$, sentrifuge $\left(\mathrm{CENTURION}^{\circledR}\right)$, oven vacum, lampu UV $245 \mathrm{~nm}$ dan $366 \mathrm{~nm}$, dan spektrofotometer UV-Vis (UNICO) 


\section{Bahan Penelitian}

Bahan-bahan digunakan pada penelitian adalah plat KLT dan serbuk silika gel $60 \mathrm{GF}_{254}$ dan $\mathrm{PF}_{254}$ serta bahan berderajat tekhnis yaitu etanol $96 \%$, aquadest, etil asetat, $n$-heksana, yang berderajat $\mathrm{Pa}$ (Pro.Analysis) yaitu metanol, $\mathrm{AlCl}_{3}, \mathrm{CHCl}_{3}$ (Kloroform), $n$-butanol, natrium metoksida, natrium asetat, $\mathrm{H}_{3} \mathrm{BO}_{3}$ (asam Borat), asam asetat glasial.

\section{Bahan Uji}

Bahan uji yang digunakan pada penelitian ini adalah buah naga merah yang sebelumnnya telah diidentifikasi Unit Pelaksana Teknis (UPT) Sumber Daya Hayati Sulawesi Universitas Tadulako dengan no. 788/UN.28 UPT-SDH/I.K/2015

\section{Cara Kerja}

\section{Pengambilan dan Pengolahan sampel}

Sampel buah naga merah (Hylocereus polyrhizus (F.A.C.Weber) Briton \& Rose) diambil di Desa Sidera, Kecamatan Sigi Biromaru, Kabupaten Sigi Provinsi Sulawesi Tengah. Sebanyak 10 kg Sampel buah naga merah segardikupas menggunakan pisau (stainless), diambil bagian dagingnya, dicuci dengan air mengalir kemudian ditiriskan lalu diblender dan dikeringkan dalam oven vacum selama 6 hari pada suhu $50^{\circ} \mathrm{C}$.

\section{Maserasi Buah Naga Merah}

Serbuk sebanyak 588,1 gram diekstraksi secara maserasi dengan menggunakan pelarut etanol 96\% sebanyak 3 liter. Perendaman dilakukan selama $3 \times 24$ jam, dimana tiap 1 x 24 jam dilakukan pengadukan kemudian di uapkan menggunakan vacuum rotary evaporator pada suhu pemanasan $70^{\circ} \mathrm{C}$ sampai didapatkan ekstrak kental.

\section{Partisi}

Sebanyak 20 gram ekstrak etanol buah naga merah dilarutkan dalam air sebanyak $100 \mathrm{ml}$. Selanjutnya dimasukkan ke dalam labu pisah lalu ditambahkan $100 \mathrm{ml} n$-heksana, dikocok secara pelahan-lahan selama 5 menit, setelah itu didiamkan hingga terjadi pemisahan antara ekstrak nheksana dan air. ekstrak $n$-heksana dipisahkan dengan lapisan air kemudian dipartisi kembali hingga 6 kali sampai larutan berwarna bening. Partisi dilanjutkan menggunakan etil asetat dengan proses yang sama dengan $n$-heksana. Ekstrak $n$-heksana cair, ekstrak etil asetat cair dan ekstrak air diuapkan sehingga diperoleh ekstrak kental.

\section{Hidrolisis Ekstrak Air}

Sebanyak $25 \mathrm{mg}$ ekstrak air dilarutkan dalam $125 \mathrm{ml}$ campuran metanol: $\mathrm{HCl} 2 \mathrm{~N}(1: 1)$ dalam gelas kimia pada penangas air selama 60 menit. Kemudian dipartisi dengan menggunakan etil asetat sebanyak $25 \mathrm{ml}$ sehingga didapatkan fraksi etil asetat hasil hidrolisis.

\section{Identifikasi Flavonoid Ekstrak Etil Asetat dan Fraksi Etil Asetat Hasil Hidrolisis}

Ekstrak etil asetat dan fraksi etil asetat hasil hidrolisis dari ekstrak air ditotolkan pada plat dengan ukuran $2 \mathrm{~cm}$ x $10 \mathrm{~cm}$ pada jarak $1 \mathrm{~cm}$ dari tepi bawah plat menggunakan pipa kapiler. Kemudian dikeringkan dan dielusi dengan eluen $n$-butanol : asam asetat glasial : air (BAA) dengan perbandingan 4:1:5. Pemisahan ekstrak etil asetat dilanjutkan dengan metode kromatografi vakum cair sedangkan untuk fraksi etil asetat hasil hidrolisis ekstrak air langsung dikromatografi lapis tipis preparatif.

\section{Pemisahan Senyawa Flavonoid Secara Kromatografi Cair Vakum}

Sebanyak 4 gram ekstrak etil asetat dilarutkan dengan metanol dan ditambahkan silika gel secukupnya, diaduk hingga homogen dan menjadi serbuk kering. Kemudian fase gerak dimasukkan pada kolom yang telah dimampatkan sebelumnya (20 g) dengan tingkat kepolarannya secara gradien, yaitu $n$-heksana $100 \%$ (2 kali), $n$-heksana:etil asetat (8:2), (6:4), (4:6), (2:8) etil asetat 100\%, etil asetat:metanol (1:1), metanol $100 \%$ masing-masing sebanyak $25 \mathrm{ml}$ (sekali).

\section{Pemurnian Menggunakan Kromatografi Lapis Tipis Preparatif (KLTP)}

Fraksi yang positif mengandung flavonoid selanjutnya dipreparatif. Eluen yang digunakan $n$ butanol:asam asetat glasial: air (4:1:5). Pita hasil KLT-P dikerok dan dilarutkan dalam pelarut metanol, kemudian disentrifuge untuk mengendapkan silikanya sehingga diperoleh supernatan lalu dikeringkan (isolat).

\section{Pemastian Kemurnian isolat dengan KLT Multi Eluen}

Isolat yang diduga mengandung flavonoid dielusi menggunakan tiga macam fase gerak dengan perbandingan yang berbeda dengan kepolaran tiap eluen berbeda yaitu $B A A(7: 0,5: 0,5)$, etil asetat : Butanol : Asam asetat ( 4:3:1), Butanol : Asam asetat galsial : Etanol (6:1:0,5). Bercak tunggal yang 
dihasilkan menandakan bahwa isolat yang diperoleh merupakan senyawa tunggal atau murni (Mathias et al, 1987)

\section{Spektroskopi Isolat}

Isolat dianalisis secara spektrofotometri UVVis dengan penambahan perekasi geser $\mathrm{NaOH} 2 \mathrm{M}$, $\mathrm{AlCl} 35 \%, \mathrm{AlCl} 3 / \mathrm{HCl}, \mathrm{NaOAc}, \mathrm{NaOAc} / \mathrm{H}_{3} \mathrm{BO}_{3}$

\section{Analisa Data \\ Data yang diperoleh dianalisis dengan cara membandingkan data-data kromatografi dan pola umum spektrum hasil spektroskopi UV-Vis dengan literatur yang telah ada}

\section{HASIL DAN PEMBAHASAN \\ Hasil Ekstrak Etanol Buah Naga Merah}

Hasil ekstrak etanol buah naga merah dari maserasi serbuk seberat 588,1 gram menggunakan pelarut etanol $96 \%$ sebanyak $1500 \mathrm{ml}$ selama $3 \times 24$ jam yaitu 209,92 gram, dengan persen rendemen sebesar $35,69 \%$

\section{Hasil Partisi Ekstrak buah Naga Merah dengan $n$ - Heksana, Etil Asetat dan Air}

Hasil partisi dengan metode partisi cair-cair dari ekstrak kental etanol buah naga merah sebanyak 20 g diperoleh ekstrak kental 2,83 gram $n$-heksana dengan persen rendemen yaitu $14,15 \%$, ekstrak kental etil asetat 3,60 gram dengan persen rendemen $18,00 \%$ dan ektrak air yaitu 9,63 gram dengan persen rendemen yaitu $48,15 \%$

\section{Identifikasi flavonoid dengan KLT}

Identifikasi senyawa flavonoid dalam ekstrak buah naga merah dilakukan dengan metode Kromatografi Lapis Tipis (KLT). Tujuannya adalah untuk mengetahui pemisahan senyawa (flavonoid) dengan eluen $n$-butanol-asam asetat glasial-air (BAA) 4:1:5 (Markham, 1988). Pemisahan ekstrak etil asetat dan fraksi etil asetat dari hasil hidrolisis ekstrak air dideteksi di bawah lampu UV 254nm dan $366 \mathrm{~nm}$ kemudian dilakukan penampakan bercak menggunakan uap amonia. Dari hasil KLT ekstrak etil asetat (gambar 1) diperoleh 2 bercak berwarna biru muda (setelah diberi uap amonia dan dibawah lampu UV $366 \mathrm{~nm}$ ). Berdasarkan perubahan warna yang terjadi pada hasil KLT fraksi etil asetat, fraksi tersebut diduga mengandung senyawa flavonoid flavon atau flavanon (Markham, 1988). Fraksi etil asetat dari hasil hidrolisis ekstrak air menghasilkan 3 bercak yaitu bercak berwarna kuning, ungu gelap, dan biru (setelah diberi uap amonia dan dibawah lampu UV $366 \mathrm{~nm}$ ). Dari perubahan warna yang terjadi pada fraksi etil asetat hasil hidrolisis ekstrak air, fraksi tersebut diduga mengandung senyawa flavonoid yaitu auron, flavon, dan isoflavon (Markham,1988).Pada pemisahan dengan KLT, eluen yang digunakan yaitu BAA (4:1:5). Hal ini karena sampel yang digunakan relatif polar sehingga kesamaan sifat antara fase gerak dan sampel dapat memberikan pemisahan yang baik. Pemisahan ekstrak etil asetat dilanjutkan dengan metode kromatografi vakum cair sedangkan untuk fraksi etil asetat hasil hidrolisis ekstrak air langsung di KLTP. Hasil penampakan noda ekstrak etil asetat dan fraksi etil asetat (hasil hidrolisis dari ekstrak air, dapat dilihat pada gambar 1.
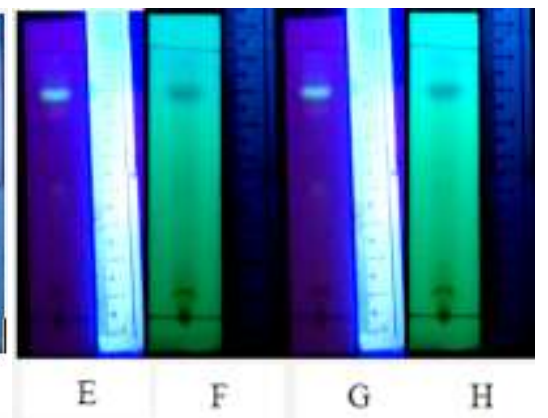

Gambar 1. Profil KLT analitik, meggunakan fase diam silika gel 60, eluen BAA (4:1:5), jarak elusi 8 cm. A: Profil KLT ekstrak etil asetat sebelum uap amonia pada lampu UV 366, B: Profil KLT ekstrak etil asetat sebelum uap amonia lampu UV 254, C: Profil KLT ekstrak etil asetat setelah uap amonia pada lampu UV 366, D: Profil KLT ekstrak etil asetat setelah uap amonia pada lampu UV 254, E: Profil KLT fraksi etil asetat sebelum uap amonia pada lampu UV 366, F: Profil KLT fraksi etil asetat sebelum uap amonia pada lampu UV 254, G: Profil KLT fraksi etil asetat setelah uap amonia pada lampu UV 366, H: Profil KLT fraksi etil asetat setelah uap amonia pada lampu UV 254 


\section{Hasil Fraksinasi Ekstrak Etil Asetat dengan Kromatografi Vakum Cair}

Pemisahan senyawa ekstrak etil asetat dilanjutkan dengan menggunakan metode kromatografi vakum cair. pelarut yang digunakan merupakan pelarut organik yang tingkat kepolarannya secara gradien meningkat, yaitu $n$ heksana $100 \%, \quad n$-heksana:etil asetat (8:2), (6:4), (4:6), (2:8) etil asetat 100\%, etil asetat:metanol (1:1), metanol $100 \%$ dengan masing-masing sebanyak 25 $\mathrm{ml}$ sehingga dihasilkan 8 fraksi. Lempeng KLT ditotolkan 8 fraksi dengan penambahan ekstrak etil asetat sebagai pembanding, kemudian dielusi menggunakan eluen $n$-butanol:asam asetat glasial:air
(4:1:5) sebanyak $40 \mathrm{ml}$. Setelah dielusi plat KLT dikeringkan kemudian diidentifikasi dengan uap amonia dan pereaksi $\mathrm{AlCl}_{3}$. Berdasarkan hasil pengamatan terdapat bercak yang berwarna biru yang diduga sebagai senyawa flavonoid. Berdasarkan profil kromatogram dari hasil KLT 8 fraksi tersebut terdapat persamaan dalam profil kromatogram sehingga dilakukan penggabungan fraksi dari 8 fraksi menjadi 3 fraksi. Hasil penampakan noda semua fraksi dibawah lampu UV 254 dan 366 nm dapat dilihat pada gambar 2, sedangkan fraksi gabungan hasil fraksinasi ekstrak etil asetat buah naga merah dapat dilihat pada tabel 1 .

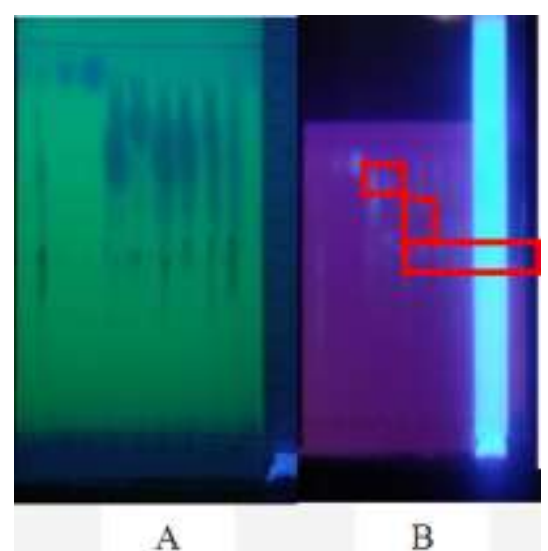

Gambar2. Profil kromatogram hasil fraksinasi ekstrak etil asetat, menggunakan fase diam silika gel $\mathrm{GF}_{254}$ dengan eluen BAA (4:1:5), jarak elusi $8 \mathrm{~cm}$. A : Profil KLT fraksi etil asetat pada lampu UV $254 \mathrm{~nm}$, B : Profil KLT fraksi etil asetat pada lampu UV $366 \mathrm{~nm}$

Tabel 1. Fraksi gabungan hasil fraksinasi ekstrak etil asetat buah naga merah

\begin{tabular}{clc}
\hline Fraksi ke- & \multicolumn{1}{c}{ Perbandingan eluen } & Bobot fraksi (gram) \\
\hline $\mathbf{1}$ & $n$-heksana $100 \%$ & 0,3 \\
& $n$-heksana : etil asetat $(8: 2)$ & 0,2 \\
$\mathbf{2}$ & $n$-heksana : etil asetat $(6: 4)$ & 2,9 \\
$\mathbf{3}$ & $n$-heksana : etil asetat $(4: 6)$ & \\
& $n$-heksana : etil asetat $(2: 8)$ & \\
& etil asetat $100 \%$ & \\
& etil asetat : metanol & \\
& metanol 100\% & $\mathbf{3 , 4 7}=\mathbf{8 6 , 7 5 \% )}$ \\
\hline
\end{tabular}

\section{Hasil Isolasi dengan Kromatografi Lapis Tipis Preparatif}

Fraksi 1,2,3, (gabungan fraksi hasil KVC) yang telah diperoleh dari proses KVC dan fraksi 4 (fraksi etil asetat dari hasil hidrolisis ekstrak air) kemudian dilakukan pemisahan dengan KLT preparatif. Plat yang digunakan adalah plat KLT silika gel 60 PF 254 dengan ukuran $20 \times 20 \mathrm{~cm}$. Setelah dilakukan proses elusi pada hasil gabungan fraksi dalam chamber, plat KLTP diamati di bawah lampu UV $366 \mathrm{~nm}$. Pada fraksi 1 menghasilkan 1 pita, fraksi 2 menghasilkan 1 pita, fraksi 3 menghasilkan 2 pita dengan semua pita (fraksi 1, 2, 3) berfluoresensi biru muda sedangkan fraksi 4 
menghasilkan pita warna kuning. Pita-pita yang dihasilkan kemudian dikerok dan dilarutkan dalampelarut metanol. Kemudian disentrifuge untuk mengendapkan silika gel atau memisahkan silika gel dan supernatan yang didapatkan sehingga di peroleh isolat. Isolasi dengan kromatografi lapis tipis preparatif fraksi 3 (gabungan $\mathrm{F} 4,5,6,7$ ) dapat dilihat pada gambar 3.

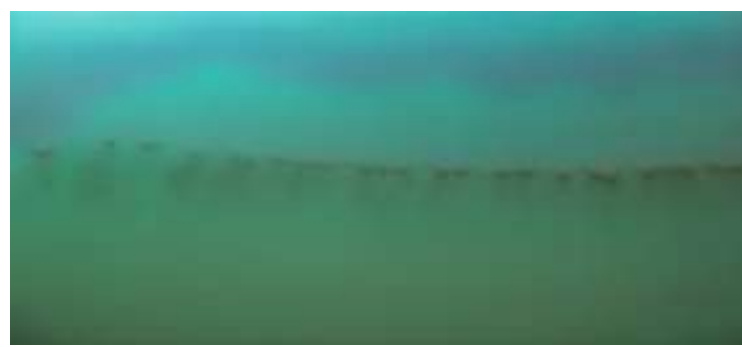

(A)

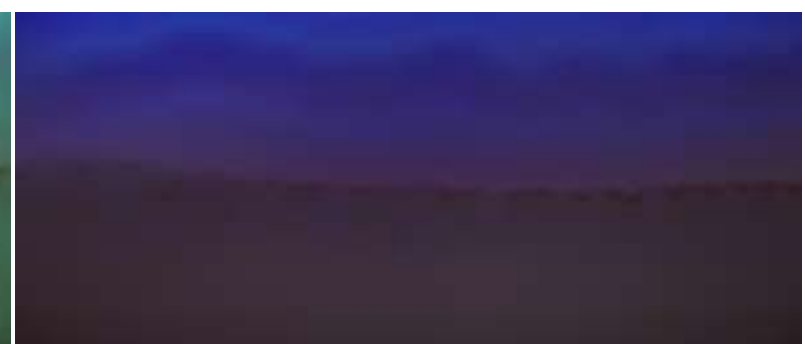

(B)

Gambar 3. Foto hasil isolasi dengan kromatografi lapis tipis preparatif menggunakan fase diam silika gel $\mathrm{PF}_{254}$, eluen yang digunakan BAA (4:1:5). A: Visualisasi KLTP pada lampu UV 254, B: Visualisasi KLTP pada lampu UV 366.

\section{Uji Kemurnian dengan Kromatografi Lapis Tipis Multi Eluen}

Isolat yang diperoleh selanjutnya diuji kemurniaannya dengan metode elusi sistem multi eluen. Tujuan dari metode ini adalah untuk melihat kemurnian isolat yang diperoleh dari hasil isolasi. Isolat ditotolkan pada lempeng KLT, selanjutnya dielusi menggunakan tiga macam fase gerak antara lain BAA $(7: 0,5: 0,5)$ etil asetat:butanol: asam asetat (4:3:1), butanol:asam asetat:etanol (6:1:5). Pemilihan eluen ini didasarkan pada perbedaan kepolaran dari masing-masing eluen yang akan memberikan profil yang berbeda pada lempeng KLT. Hasil elusi dengan ketiga eluen tersebut menghasilkan hanya satu bercak. Berdasarkan hal tersebut isolat dapat dikatakan murni secara KLT. Kemurnian dengan KLT multi eluen dengan menggunakan 3 perbandingan eluen dengan kepolaran berbeda, dapat dilihat pada gambar 4 .

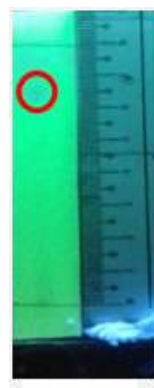

A

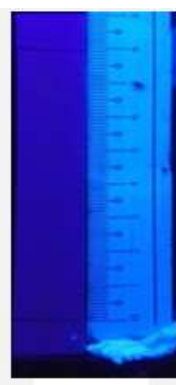

B

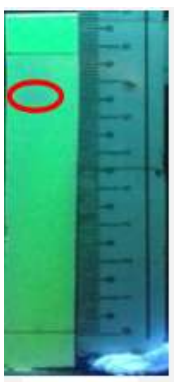

$\mathrm{C}$

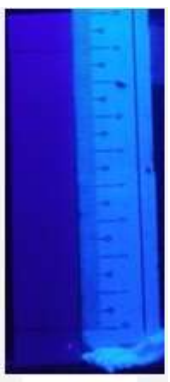

D

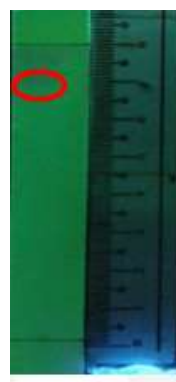

E

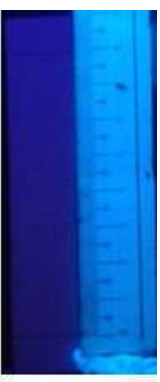

F

Gambar 4. Profil KLT multi Eluen meggunakan fase diam silika gel 60. A: Penampakan KLT multi eluen BAA $(7: 0,5: 0,5)$ pada lampu UV 254, B: Penampakan KLT multi eluen BAA (7:0,5:0,5) pada lampu UV 366, C: Penampakan KLT multi eluen etil asetat:butanol: asam asetat (4:1:3) pada lampu UV 366, D: Penampakan KLT multi etil asetat: butanol : asam asetat (4:1:3) pada lampu UV 366, E: Penampakan KLT multi eluen butanol: asam asetat glasial: etanol $(6: 1: 0,5)$ pada lampu UV 254 nm, F: Penampakan KLT multi eluen butanol: asam asetat glasial: etanol (6:1:0,5) pada lampu UV $366 \mathrm{~nm}$

\section{Identifikasi Dengan Spektrofotometer Ultraviolet UV-Vis}

Berdasarkan hasil spektroskopi UV-Vis isolat $1,2,4$, dan 5 tidak menunjukkan pola umum spektrum senyawa flavonoid, sedangkan isolat 3 memberikan serapan maksimum pada panjang gelombang $330 \mathrm{~nm}$ (pita I) dan $280 \mathrm{~nm}$ (pita II). Menurut Markham (1988), senyawa flavonoid dengan serapan maksimum pita I pada panjang gelombang 300-330 nm dan pita II pada $275-295 \mathrm{~nm}$ termasuk dalam golongan flavanon atau dihidroflavonol, sehingga dugaan senyawa dari isolat 3 adalah golongan flavanon atau dihidroflavonol. Hasil analisis spektrofotometri UV-Vis dengan melakukan scan panjang gelombang 200-600 nm dapat dilihat pada gambar 5 . 


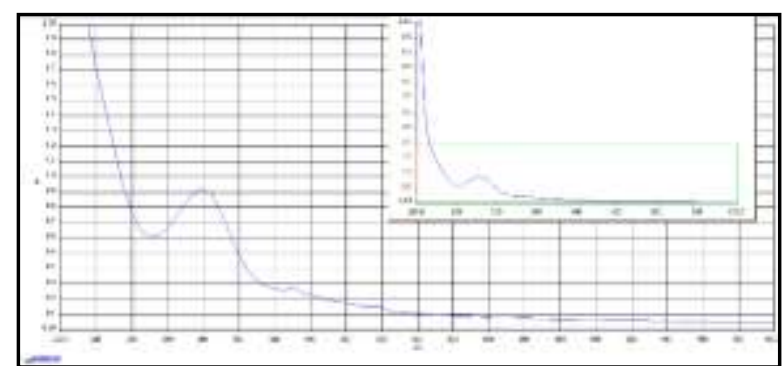

Gambar 5. Hasil spektroskopi UV-Vis isolat 3, pelarut metanol.

Hasil spektrofotometri UV-Vis isolat dengan penambahan pereaksi geser $\mathrm{NaOH} 2 \mathrm{M}, \mathrm{AlCl}_{3} 5 \%$, $\mathrm{AlCl}_{3} / \mathrm{HCl}$, NaOAc, $\mathrm{NaOAc} / \mathrm{H} 3 \mathrm{BO} 3$ dapat dilihatpada tabel 2. Tujuan penambahan pereaksi geser adalah untuk menentukan kedudukan gugus hidroksi pada inti flavonoid (markham, 1988). Pada penambahan pereaksi $\mathrm{NaOH}$ tidak menunjukkan pergeseran batokromik dan hipsokromik pada pita I dan II. Hal ini menunjukkan tidak terdapat gugus orto hidroksi pada cincin A. Pada penambahan pereaksi geser $\mathrm{AlCl}_{3}$ dan $\mathrm{AlCl}_{3}$ yang ditambahkan $\mathrm{HCl}$ juga tidak menunjukkan pergeseran batokromik dan hipsokromik. Berdasarkan hal tersebut pula menggambarkan tidak adanya gugus orto dihidroksi pada C-4', C-5' dan tidak adanya gugus hidroksi pada atom $\mathrm{C}-3$ dan $\mathrm{C}-5$ yang dapat membentuk kompleks apabila berikatan dengan gugus keto dengan bantuan $\mathrm{AlCl}_{3}$. Tidak adanya gugus hidroksi pada atom C-3 dan C-5 menandakan bahwa isolat 3 bukan merupakan golongan dihidroflavonol, namun menunjukkan ciri dari senyawa flavonoid golongan flavanon (Setiawan, 2008). Pada penambahan pereaksi NaOAc dan $\mathrm{H}_{3} \mathrm{BO}_{3}$, hasil spektroskopinya menghasilkan tidak adanya pergeseran apapun dan hal tersebut menunjukkan tidak terdapatnya gugus orto hidroksi. Berdasarkan hal tersebut isolat 3 diduga merupakan golongan senyawa flavonoid dengan inti flavanon.

Tabel 2. Panjang gelombang maksimum dari isolat setelah penambahan pereaksi geser

\begin{tabular}{|c|c|c|c|c|c|c|}
\hline \multirow[b]{2}{*}{ Isolat } & \multicolumn{6}{|c|}{ Panjang gelombang maksimum (nm) dengan penambahan pereaksi geser } \\
\hline & МeOH & $\begin{array}{c}\mathrm{MeOH}+ \\
\mathrm{NaOH}\end{array}$ & $\begin{array}{c}\mathrm{MeOH}+ \\
\mathrm{AlCl}_{3}\end{array}$ & $\begin{array}{c}\mathrm{MeOH}+ \\
\mathrm{AlCl}_{3} / \mathrm{HCl}\end{array}$ & $\begin{array}{l}\mathrm{MeOH}+ \\
\mathrm{NaOAc}\end{array}$ & $\begin{array}{c}\mathrm{MeOH}+ \\
\mathrm{NaOAc} / \mathrm{H}_{3} \mathrm{BO}_{3}\end{array}$ \\
\hline 1 & - & - & - & - & - & - \\
\hline 2 & - & - & - & - & - & - \\
\hline \multirow[t]{2}{*}{3} & 330 & - & - & - & - & - \\
\hline & 280 & 280 & 280 & 280 & 280 & 280 \\
\hline 4 & - & - & - & - & - & - \\
\hline 5 & 325 & - & - & - & - & - \\
\hline
\end{tabular}

\section{UCAPAN TERIMA KASIH}

Terima kasih kepada Ramadanil Pitopang (Professor Botani) dan Kanda Sahlan yang telah membantu mengidentifikasi tumbuhan yang dilakukan dalam penelitian.

\section{DAFTAR PUSTAKA}

Asih, A.R, Ratnasaari K, Swardana B.I. (2012). Isolasi dan identifikasi senyawa golongan flavonoid dari madu kelengkeng (Nephelium longata L), (Skripsi) Universitas Udayana.
Feranose, P. (2009). Pengaruh pemberian buah naga merah (Hylocereus polyrhizus) terhadap kadar glukosa darah tikus putih yang diinduksikan aloksan, (Skripsi) Fakultas Kedokteran Universitas Sebelas Maret Surakarta.

Jaafar A.R, Ridwan. A, Mahmod. C.Z. (2009). Proximate analysis of dragon fruit (Hylecereus polyhizus) Universitas Putra Malaysia, Selanggor, Malaysia 
Markham K.R, (1988), Cara Mengidentifikasi Flavonoid, Padmawinata K, penerjemah, Penerbit ITB, Bandung.

Mathias, O., Hamburger, and Geoffrey, A.C. (1987). A direct bioautographic assay for compounds possessing antibacterial activity, Journal of Natural Products, Vol. 50(1): $19-22$

Patni. V, Meena. C, Mahesh. (2008). Isolation and identification of flavonoid quercetin from Citrullus colocynthis (Linn.) Schrad, University of Rajasthan, India.
Rohyami, Y. (2008), Penentuan kandungan flavonoid dari ekstrak metanol daging buah Mahkota Dewa (Phaleria macrocarpa Scheff Boerl), (Skripsi) Universitas Islam Indonesia, Yogyakarta

Setiawan adi. MI, Asih Astiti R.A.I. (2008). Senyawa golongan flavonoid pada ekstrak n-butanol kulit batang bungur (Lagerstroemia speciosa Pers.), (Skripsi) Jurusan Kimia FMIPA Universitas Udayana, Bukit Jimbaran

Winarsih. (2007). Mengenal dan membudidayakan buah naga. CV Aneka Ilmu, Semarang. 